\title{
Material Texts and Medical Libraries in the Digital Age
}

The College of Physicians of Philadelphia was founded in 1787; the College Library was founded a year later. At the time of its founding, as for hundreds of years prior, a library was an essential medical workplace, the site of knowledge production, more significant than an anatomy theater, and much more so than the workrooms that were evolving into the spaces called laboratories. Over its 225 years, the College Library has been at the heart of Philadelphia medicine; and, as the discipline of the history of medicine has developed, the Library has become a crucial resource for historians of medicine, such as myself. I first did historical research at the library while in graduate school, and I have pursued various research topics in the college's collections ever since. Here, I want to explore the value of libraries such as this in a moment when much librarianship is going digital. I argue that encounters with material texts-with the actual leather, ink, and paper of the books themselves - are a crucial element of historical scholarship. ${ }^{2}$

In particular, some of the books in the College Library's collection emphasize the complicated intertwining of manuscript and print that make close examination of the material text so valuable. While scholars such as Harold Love have reminded us that the circulation of texts in manuscript form remained a significant form of "publication" for centuries after the invention of moveable-type printing, here I emphasize a series of other relationships, such as marginalia and the circulation between print and manuscript, which tells us much both about medicine and about print. ${ }^{3}$ It is a Philadelphia story, not least because Philadelphia was the most significant site in the American colonies and the new nation for both medicine and the print industry.

1. This paper was given at the symposium celebrating the 225th Anniversary of the Historical Medical Library of The College of Physicians of Philadelphia. It is a pleasure to acknowledge Annie Brogan and Christine Ruggere for all of their help with this paper.

2. Peter Stallybrass, "The Library and Material Texts," PMLA 119 (2004): 1347-52.

3. Harold Love, Scribal Publication in Seventeenth-Century England (Oxford: Clarendon, 1993); William Sherman, Used Books: Marking Readers in Renaissance England (Philadelphia: University of Pennsylvania Press, 2008); H.J. Jackson, Marginalia: Readers Writing in Books (New Haven: Yale University Press, 2001). 
The College Library's holdings go much further back in time than the founding of the library itself. For medical practitioners in the eighteenth century, there was no bright line between "medicine" and "history of medicine"; medical practice was still grounded in theories dating back to classical antiquity, so old books might offer clinical insights. The collection's holding of incunables-that is, books printed before 1501 - is among the thirty or so largest of any library in North America. While at times we cannot trace the specific provenance of an individual volume, the library was a working collection built by and for physicians in practice.

The College Library's copy of the Herbarius, an herbal published in 1486 in Louvain, shows us the intertwining of print and manuscript and how paying close attention to the material text can reveal much about the uses to which an individual book was put. ${ }^{4}$ The first page has a manuscript initial and rubrication, just as would a manuscript. None of the authorities cited in the book, such as Avicenna, the great medieval Arabic physician whose works formed the core of the medical curriculum, wrote after 1300, so scholars suggest that the Herbarius was based upon a medical manuscript composed pre-1300.

With books this old, there are truly no duplicates; each copy is individual and can tell historians about how it was made and used. This one, for example, was used very heavily. A sixteenth- or early seventeenth-century reader noted down additional plants he had seen or heard about. Throughout the book, this reader made it his own: for example, writing French names next to the printed Latin and Low Dutch names of plants or reminding himself that plantain is a good remedy for ailments of the liver, either as juice or in poultice form. So, in the first generation of printed books, someone has used this book as a way of organizing and compiling knowledge he himself brings to the book; his own botanical experience is captured on the page in a kind of dialogue between plants in the world and plants in the book. For all its riches, this is a surprisingly small volume. One scholar has noted that the 148 plants described here all were native to or cultivated in the German-speaking lands; local knowledge, produced mostly for a local readership, embedded in a framework of medical learning (Avicenna and the like) that was Europe-wide. ${ }^{6}$ Over the next two centuries, voyages of exploration and empire would change all that.

4. Herbarius in latino cum figuris (Louvain: Jan Veldener, 1486).

5. Agnes Arber, Herbals, Their Origin and Evolution: A Chapter in the History of Botany, 1470-1670 (Cambridge: Cambridge University Press, 1938); Karen Meier Reeds, Botany in Medieval and Renaissance Universities (New York: Garland, 1991); Visualizing Medieval Medicine and Natural History, 1200-1550, eds. Jean A. Givens et al. (Burlington, Vt.: Ashgate, 2006); Minta Collins, Medieval Herbals. The Illustrative Traditions (London: The British Library, 2000). On readers, see Rebecca Laroche, Medical Authority and Englishwomen's Herbal Texts, 1550-1650 (Burlington, Vt.: Ashgate, 2009).

6. Arber, Herbals, 22. On local knowledge, see Alix Cooper, Inventing the Indigenous: Local Knowledge and Natural History in Early Modern Europe (Cambridge: Cambridge University Press, 2007). 


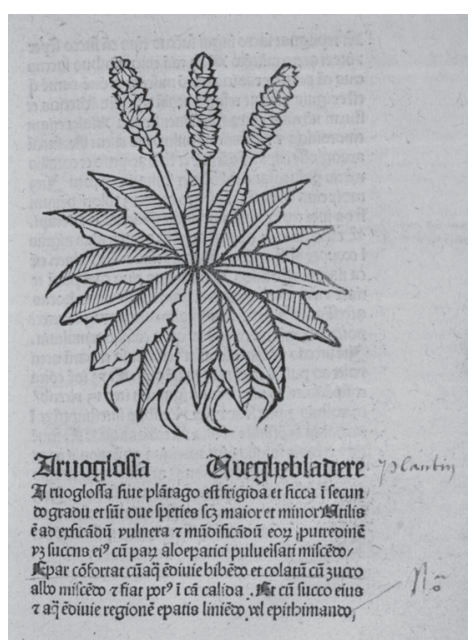

Figure 1. Herbarius in latino cum figuris, 1486. Courtesy of The College of Physicians of Philadelphia.
Less than a decade later, a much larger herbal was published in Mainz, the Hortus Sanitatis, or Garden of Health. ${ }^{7}$ The College Library's copy is a late-medieval luxury good, with hand-colored pictures on every page and elaborate wooden covers once closed by metal clasps. It is a huge compendium, including many plants as well as animals, insects, birds, fishes, and gems. There are some unexpected entries, like manna, sirens, and unicorns. The book includes animals not often found in German lands, such as camels. More important for healers, it included extensive discussions of exotic plants such as cassia and cinnamon. While a German would not have seen a cassia tree growing, he or she might be able to purchase the spice in a market. ${ }^{8}$ Compared to the Herbarius, this is a cosmopolitan volume, full of knowledge about the Mediterranean world, not just the German-speaking lands. ${ }^{9}$

Like the College's copy of the Herbarius, the Hortus was a working copy. The book was meant to be used for healing. At the end, it includes a list of what plants cured what, starting with "Ad Alopecia," or herbs that might cure baldness, and so on through troubles with hearing and aposthumes. At the very back of the book is a list of all the herbs included, and an early modern reader has listed translations into Flemish or German of the Latin names. Not every plant was known to this reader; he or she has only noted synonyms for about a third. This is humanist botany, in which both the plants themselves and their names are fully worthy of study. ${ }^{10}$ There is also a whole page of manuscript notes, which the writer has carefully rubricated. In effect, the writer was copying the rubrication of the printed text, which was itself echoing manuscript production, a cycle of imitation and reuse that complicates any simple model of transition from manuscript to print. Annotated books like this, read carefully, can tell us much about the mental worlds of their readers, as well as their authors.

7. Hortus Sanitatis (Mainz: Jacob Meydenbach, 1491).

8. Paul Freedman, Out of the East: Spices and the Medieval Imagination (New Haven: Yale University Press, 2008).

9. On Renaissance natural history, see Brian W. Ogilvie, The Science of Describing: Natural History in Renaissance Europe (Chicago: University of Chicago Press, 2006).

10. Vivian Nutton, "The Rise of Medical Humanism: Ferrara, 1464-1555," Renaissance Studies 11 (1997): 2-19. 
A similar transit between manuscript and print can be seen in early modern recipe books. While herbals are organized by plant, recipe books were often compiled over time, with the order of the recipes determined by the compiler according to his or her needs. ${ }^{11}$ Such works provide a valuable window into domestic medical practice, showing many of the men and women who made these books to be sophisticated consumers and producers of medical knowledge that circulated between manuscript and print and back again repeatedly.

The College Library has a rich example of this genre in the recipe book of Elizabeth Paschall, who lived in Philadelphia in the mid-eighteenth century. ${ }^{12}$ For Paschall, knowledge was deeply relational; it often came from someone in a particular social interaction. She collected a recipe to heal a deep puncture wound from a "High German," who had had the misfortune to run a nail into his hand three days prior. Paschall "was verry inquisitive" about his method of cure because, when she saw it, "it was perfectly well Except the Scab." The High German "was his own Doctor" and told her that he used a simple method: he applied ear wax from his own ear to the wound, after washing the wound with rum and turkey fat. He tells Paschall that many people in Germany knew the benefit of this method and even saved up ear wax for the purpose.

Then Paschall was off and running, using her social networks to evaluate this startlingly simple remedy. Her friend Killian White assured her that this was the only remedy he used for such an injury and that his father-in-law "Old John Lucas," one of the first settlers - whom Paschall had known when she was a child—always recommended it. Then Paschall tried on one of her maids, who had run a nail deep into her hand, and the wax "Eased it and cured it very soon." ${ }^{.13}$ Although historians

11. For some pioneering works, see Jennifer K. Stine, "Opening Closets: The Discovery of Household Medicine in Early Modern England” (PhD diss., Stanford University, 1996); Elaine Leong, "Medical Recipe Collections in Seventeenth-Century England: Knowledge, Text and Gender" (DPhil diss., Oxford University, 2005); Alisha Rankin, Panaceia's Daughters: Noblewomen as Healers in Early Modern Germany (Chicago: University of Chicago Press, 2013); Catherine Field, "Many Hands Hands': Writing the Self in Early Modern Women's Recipe Books," in Genre and Women's Life Writing in Early Modern England, eds. Michelle Dowd and Julie Eckerle (Aldershot: Ashgate, 2007), 49-63.

12. Elizabeth Coates Paschall, Receipt Book, 1749-66, Cage 10a 352, The College of Physicians of Philadelphia. See Ellen G. Gartrell, "Women Healers and Domestic Remedies in 18th Century America: The Recipe Book of Elizabeth Coates Paschall," New York State Journal of Medicine, 87.1 (1987), 23-29, reprinted in Early American Medicine: A Symposium, eds. Robert I. Goler and P.J. Imperato (New York: Fraunces Tavern Museum, 1987), 15-21. See also the extensive Paschall manuscripts in the William Henry Russell collection of Morris family papers, 1684-1935: Series I. Samuel Morris at the Hagley Library, Wilmington, Del.: Volume 26: Receipt book of Elizabeth Paschall, 1741 December 3-1750 August 25; Volume 27: Receipt book of Elizabeth Paschall, 1750 June $27-1762$ January 28 [includes signatures of early Philadelphians]; Volume 29: Recipes for cure of various ailments and afflictions from Elizabeth Paschall's recipe book, 1780 January 24-1780 April 17. Many thanks to Christine Ruggere for these references and much else.

13. Elizabeth Coates Paschall, Receipt Book, 1749-66, no page number, Cage 10a 352, The College of Physicians of Philadelphia. 
have only recently recognized it as such, Paschall was doing a kind of artisanal science here, building knowledge through a series of trials and tests. ${ }^{14}$

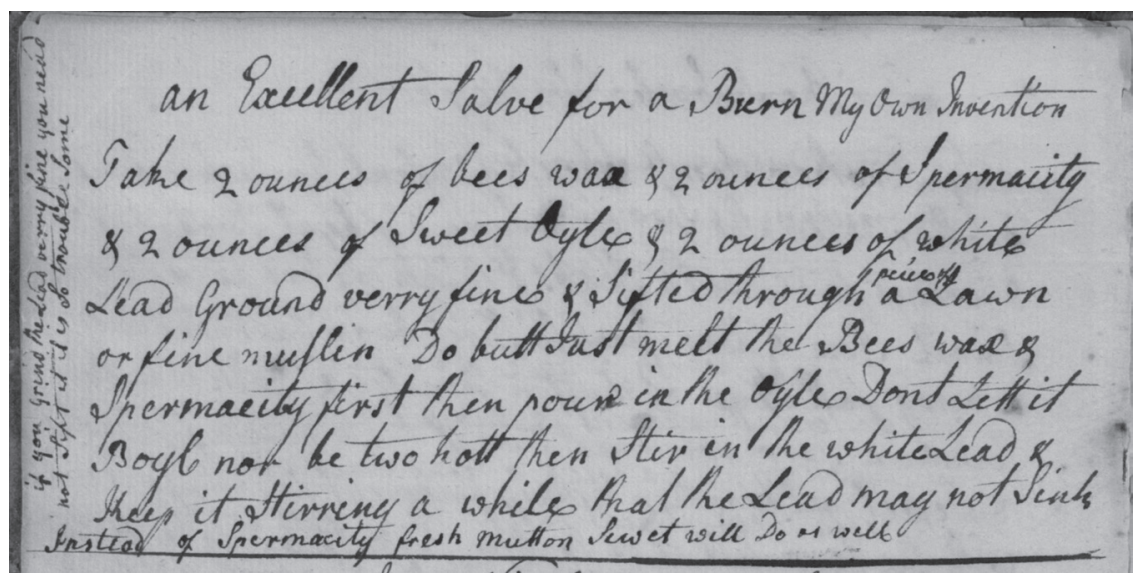

Figure 2. Elizabeth Coates Paschall, Receipt Book, 1749-66. Courtesy of The College of Physicians of Philadelphia.

Another recipe, a salve for a burn, shows us how Paschall used an iterative process to develop a remedy. It is, she noted, "My Own Invention." The recipe has been through a testing process that leads to a number of refinements, which have been added as marginal notes. Don't heat the wax too much; fresh mutton suet can be used instead of the spermaceti; you can omit sifting the white lead if you grind it up very fine. ${ }^{15} \mathrm{~A}$ book such as this changes the way that we think about women healers in the colonial period-all of a sudden there might have been lots of them, not merely in the more obvious occupational category of midwives, but many Elizabeth Paschalls, quietly healing in a domestic context, making new remedies, exchanging them with others, trying and testing to build a reliable domestic pharmacopeia.

At the same time that Paschall was living and working in Philadelphia, so too was one of the city's greatest physicians, Benjamin Rush, author, signer of the Declaration of Independence, and Fellow of The College of Physicians of Philadelphia. The College Library has a wealth of materials associated with Rush; in this paper I will focus on just two items. First is a few sheets of paper apparently drawn from a

14. On artisanal science, see, for example, Pamela H. Smith, The Body of the Artisan: Art and Experience in the Scientific Revolution (Chicago: University of Chicago Press, 2004); Deborah Harkness, The Jewel House: Elizabethan London and the Scientific Revolution (New Haven: Yale University Press, 2007). For such everyday natural knowledge in the early American context see, for example, Sara S. Gronim, Everyday Nature: Knowledge of the Natural World in Colonial New York (New Brunswick, N.J.: Rutgers University Press, 2007).

15. Elizabeth Coates Paschall, Receipt Book, 1749-66, fol. 3v, Cage 10a 352, The College of Physicians of Philadelphia. 
larger manuscript note book. These pages are about the closest we can get to eavesdropping on Rush's thoughts. He asks himself about the Biblical substance manna, and it is like seeing the Enlightenment made manifest. Rush is asking naturalistic questions of Biblical events. Was manna made of oil and sugar? Rush reminds himself to ask about "the sensible and physical qualities of the manna in the old testament" - not its miraculous qualities. ${ }^{16}$

Rush then speculates about what will happen to the human body at the day of judgement. "That our saviour put off his infirmities \& Deformity after his resurrection is evident from his disciples not knowing him afterwards." ${ }^{17}$ The state of the resurrected body was an item of concern for many in the eighteenth and early nineteenth centuries. People worried about what would happen, for example, to people who had been drowned and whose bodies had been eaten by sharks. Or people who'd lost a limb on a battlefield—would they be reunited with their missing limb on Judgment Day $?^{18}$ But Rush is not speculating in some kind of vacuum. On the same page he mobilizes specific evidence for another point from his own experience: "Job Scott, a Quaker preacher, felt as if all his bones were bruised the morning after a night of great anguish of Soul. See his Journal." Here Rush is struggling to relate the world of the body and the soul, just as in the case of Jesus's new improved post-Resurrection body. Job Scott was a traveling Quaker preacher, known as a quietist, whose Journal documents some 5,000 miles of travel preaching up and down the East Coast. ${ }^{19}$ Rush was a man of faith, but that faith sits alongside a lively scientific curiosity grounded in material particulars of everyday life in Philadelphia.

The second Rush source also connects manuscript and print, in two manuscript notebooks in the College Library's collection, containing notes taken by John Archer in 1797 at lectures at the University of Pennsylvania where he was at medical school..$^{20}$ As Melissa Grafe has shown, Archer came to the University of Pennsylvania after an intensive medical training from his father, also John Archer, who lived in Harford County, Maryland. He trained so many apprentices in medicine that the students formed a kind of medical society of their own; his home was referred to as "Medical Hall." 21 John Archer junior seems to have been a diligent student. The first notebook starts with a lecture in his Pathology course; it is on "Disease

\footnotetext{
16. Benjamin Rush, Notes (Fragmentary) on Medical Matters Mentioned in the Bible, with Biblical References, Rush MSS 10a/250 12, The College of Physicians of Philadelphia.

17. Ibid.

18. Ruth Richardson, Death, Dissection and the Destitute (London: Routledge and Kegan Paul, 1987).

19. See Job Scott, Journal of the Life, Travels, and Gospel Labours of That Faithful Servant and Minister of Christ, Job Scott (New York: Isaac Collins, 1797).

20. John Archer, Lecture Notes on Rush's Lectures on the Institutes of Medicine, Cage 10a453, The College of Physicians of Philadelphia.

21. Melissa Grafe, "Making 'Medical Hall': Dr. John Archer, Medical Practice, and Apprenticeship in Early America, 1769-1820” (PhD diss., Johns Hopkins University, 2010).
} 
and the origin of Moral and Natural Evil," which he heard on 21 December 1796. The students did not get much holiday over Christmas; John heard a lecture on 23 December and was back again taking notes on 26 December.

Archer was an assiduous note-taker. These notebooks, each of which cover only a few weeks of lecture, must have been part of a very much larger set-one of these says "to 60 " at the back, I think referring to the fact that his notes for this course are continued in Notebook number 60. One of the delightful aspects of these notebooks is their material form. These are notebooks that Archer probably bought in Philadelphia. Their covers have pictures on them that were images from Aesop's Fables. Originally I thought these were some kind of waste paper, proofs perhaps, but it turns out that notebooks, or copybooks as they were called, often had such images on their covers, much as we buy school notebooks for children with Teenage Mutant Ninja Turtles or Batman on the covers! Aesop's Fables have a long history of serving as political commentary—they were not by any means merely copied from book to book. ${ }^{22}$ Here on Archer's notebook, they do so again. The fable called "The Aristocrat Gets Flogged" has a handwritten note underneath the image, "Democrats desert":, that is, the Democrats deserved to get flogged, just like the aristocrat.

I am sure that whoever saved John Archer's two books of lecture notes did so because they were associated with the great Benjamin Rush, not because they had Aesop's Fables illustrations on their covers. But we now have a much deeper appreciation of the vital role of print in both the American Revolution and in the complex process of forging a new political nation thereafter-and so we have a new appreciation of the roles of printers and publishers. ${ }^{23}$ So-called "jobbing printers" - the ones who printed everyday stuff, like notebook covers, tickets to events, record books, and the like, played a vital role in keeping the economy of printing afloat; so that when some big political event happened, there were presses ready and waiting to print up a broadside in thousands of copies and spread the news. ${ }^{24}$ The mute witness of those notebook covers gives us just a glimpse of those presses; and this particular manuscript comment gives us a flavor of the kinds of

\footnotetext{
22. Annabel Patterson, Fables of Power: Aesopian Writing and Political History (Durham, N.C.: Duke University Press, 1991); Tomoko Hanazaki, "A New Parliament of Birds: Aesop, Fiction, and Jacobite Rhetoric," Eighteenth-Century Studies 27 (1993/4): 235-55.

23. See, for example, John R. Howe, Language and Political Meaning in Revolutionary America (Amherst: University of Massachusetts Press, 2004); Michael Warner, The Letters of the Republic: Publication and the Public Sphere in Eighteenth-Century America (Cambridge, Mass.: Harvard University Press, 1990).

24. Trish Loughran, The Republic in Print: Print Culture in the Age of U.S. Nation Building, 1770-1870 (New York: Columbia University Press, 2007). For a helpful overview, see James N. Green, "The Rise of Book Publishing in the United States, 1785-1840," in A History of the Book in America, Vol. 2, eds. Robert A. Gross and Mary Kelley (Chapel Hill: University of North Carolina Press, 2010). On the Philadelphia print trade, see James N. Green and Peter Stallybrass, Benjamin Franklin: Writer and Printer (New Castle, Del.: Oak Knoll Press, 2006).
} 
informal political discourse found in taverns and streets that made the new nation a new kind of democracy.

To conclude, I want to look at another way that some of the treasures of the College Library's collection speak to the complex interplay of print and manuscript. While Rush lectured, wrote, and practiced, many a Philadelphian turned for advice on matters reproductive to a small book called Aristotle's Masterpiece, the subject of my current research. It was the core vernacular text on making babies from almost its first publication in 1684 well into the nineteenth and even twentieth centuries, and it was still being republished and sold into the 1930s in London. Several editions were published in Philadelphia. The book is basically a late-seventeenthcentury midwifery guide; it offers both midwives and mothers information about generation (roughly what we would call conception and development), pregnancy, childbirth, and care of the newborn. ${ }^{25}$

And, of course, it is not really by Aristotle. The title is a nod to the fact that Aristotle had a reputation as a sex expert in seventeenth-century England, as well as being the most significant classical authority on generation. We do not know who actually wrote the book. Like many medical texts intended for ordinary readers, the book is composed of older texts-in this case, from the sixteenth century.

The Masterpiece rapidly became a bestseller/steady seller: by the mid-eighteenth century, there were more editions of it than all other popular books on reproduction combined. Many nineteenth-century editions are currently for sale in antiquarian bookshops and on the Internet. A variety of printers and publishers took it on, producing at least four different versions of the core text. It was often packaged with three other pseudo-Aristotle texts, sold together as the delightfully misleadingly titled Aristotle's Works. The Masterpiece was produced on average every year for 250 years. The College Library has a rich array of Aristotle's Masterpieces that were produced in a dizzying array of formats.

Probably my very favorite copy in the College Library's collection is a small one published in London in $1731 .{ }^{26}$ Someone, most likely in the eighteenth century, painstakingly stitched his or her copy of the book back together. This was not professional or even amateur bookbinding - it was a wholly improvisational patch-up. It tells me that this book was very well used, and valued by its owner, who was not

25. On the Masterpiece, see Mary E. Fissell, "Hairy Women and Naked Truths: Gender and the Politics of Knowledge in Aristotle's Masterpiece," William and Mary Quarterly 60 (2003): 43-74; and "Making a Masterpiece: The Aristotle Texts in Vernacular Medical Culture," in Right Living: An Anglo-American Tradition of Self-Help Medicine, ed. Charles E. Rosenberg (Baltimore: Johns Hopkins University Press, 2003), 59-87.

26. Aristotle's compleat master-piece. In three parts. 18th ed. (No city: Printed and sold by the booksellers, 1731) [The College of Physicians of Philadelphia, GGa 5 1731]. 
a book person with a large library and an ongoing relationship with a bookbinder, of whom there were at least half a dozen in Philadelphia in the middle of the eighteenth century. ${ }^{27}$ This was an ordinary reader who wanted to keep his or her battered copy intact.

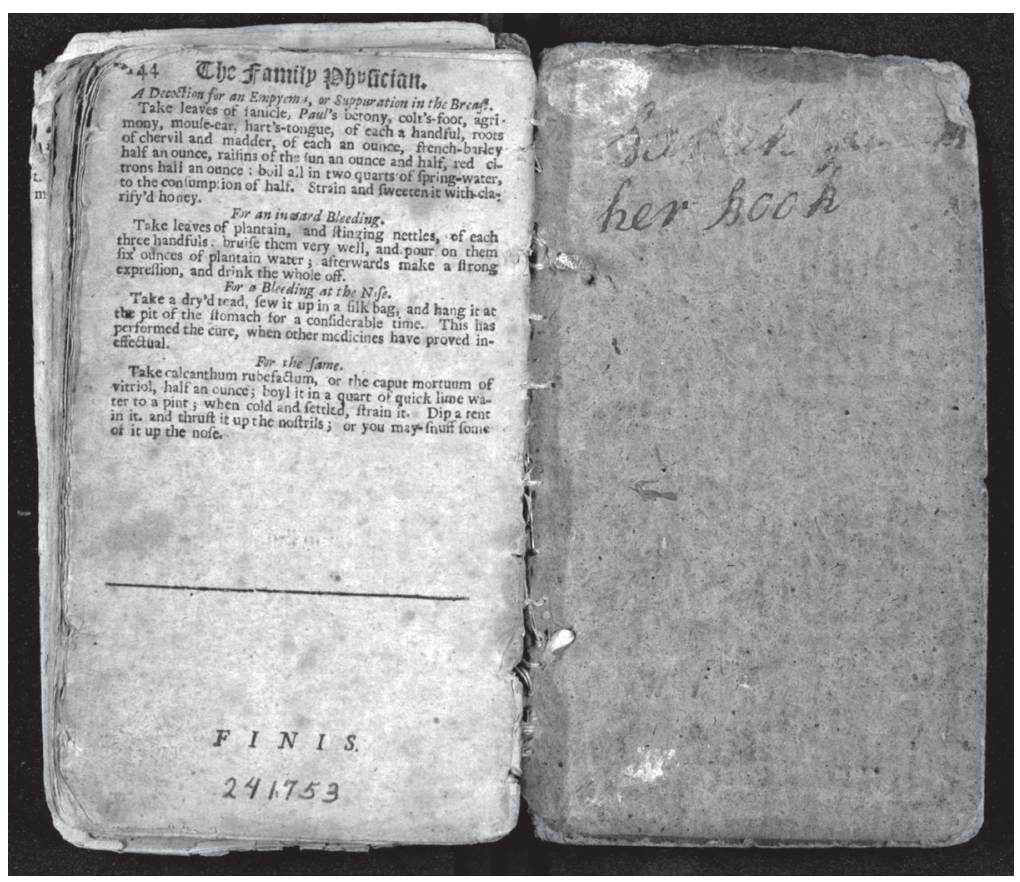

Figure 3. Aristotle's compleat master-piece. In three parts. 18th edition, 1731. GGa 5 1731. Courtesy of The College of Physicians of Philadelphia.

Finding such ordinary readers is not easy. Reading is a silent activity, and the Masterpiece was a small book that could be tucked into all kinds of domestic spaces. In Northampton, Massachusetts in 1745, Jonathan Edwards, later to gain fame as a minister and president of Princeton, was struggling to manage his first parish. He found that the teenage boys of the parish were reading Aristotle's Masterpiece and teasing the girls with it. ${ }^{28}$ Luckily for historians of the book, he wrote down his questions and answers, so we know a lot about the traffic of the book in Northampton. Unluckily for Edwards, he handled the episode poorly; the most important men of the parish were not best pleased to have their sons denounced from the pulpit for their involvement in the scandal. Edwards' notes indicate that

27. According to C. William Miller, Benjamin Franklin's Philadelphia Printing, 1728-1766: A Descriptive Bibliography (Philadelphia: American Philosophical Society, 1974), xlvi. Benjamin Franklin used a dozen bookbinders over the period 1728-66, although only some were active at any one time. Many thanks to James Green for help on this point and many others.

28. Fissell, "Making a Masterpiece." 
there were actually at least two midwifery books circulating in the parish, and that one of these books was kept in a small cupboard built into a chimney, while the Masterpiece was hidden under a teenage boy's mattress for several months!

There were a fair number of these adolescent male readers of the book: John Cannon, a Somerset teen who borrowed his mother's copy, along with her copy of Culpeper's midwifery book around 1700 because he wanted to know what women looked like under their clothes; or Francis Place, who read the Masterpiece while a schoolboy in late-eighteenth century London. ${ }^{29} \mathrm{I}$ began to get discouraged-I had begun working on the Masterpiece because I was interested in women's ideas about the body. But when young men read the book, it was exceptional, transgressiveand likely to get written down. In the Northampton episode, for example, the book was never named, it was called a "granny book": that is, a book for women. What's wrong was not the book itself but the fact that it was being read by readers who should not have been reading it and who were using it inappropriately-which is why these particular readers entered the historical record.

So, to find female readers, I have begun to pay much more attention to ownership inscriptions in the book, often on the front or back flyleaf. In that same stitchedtogether 1731 edition, a woman has written her name: we can just make out "Sarah," but the last name has been completely worn away. I wish that we could have a few more details, like a last name and a place, but I am beginning to find a number of such female readers-there's Alice Burton in a copy at the New York Academy of Medicine, Elizabeth Vincent and Sarah Fackerall, two different women readers, separated by a century, in a first edition in the University of Pennsylvania's Van Pelt Library, and at Johns Hopkins there is a first edition inscribed by Elizabeth Wright. ${ }^{30}$ In the eighteenth century, fewer women could write than read. Reading and writing were skills taught separately at school, and a girl might learn reading and, say, a form of needlework, rather than reading and writing. ${ }^{31}$ So these female readers who wrote their names in copies of the Masterpiece suggest the extent of an almost invisible female readership. It is never going to be quantifiable or precise.

29. John Cannon, Memoirs, 48, DD/SAS C/1193/4, Somerset Record Office; Francis Place, The Autobiography of Francis Place, ed. Mary Thale (Cambridge: Cambridge University Press, 1972), 45. 30. Aristotle's compleat master-piece. In three parts. 15th ed. (London: Printed and sold by the booksellers, 1723) [New York Academy of Medicine, RB 23]; Aristotle's master-piece: or the secrets of generation display'd in all the parts thereof (London: Printed for J. How, and are to be sold next door to the Anchor Tavern in Sweetings Rents in Cornhil, 1684) [Van Pelt Library, University of Pennsylvania, EC65 A100 684a2]; Aristotle's master-piece: or the secrets of generation display'd in all the parts thereof (London: Printed for J. How, and are to be sold next door to the Anchor Tavern in Sweetings Rents in Cornhil, 1684) [Institute of the History of Medicine, The Johns Hopkins University, Vault .A7171a 1684].

31. Reading Women: Literacy, Authorship, and Culture in the Atlantic World, 1500-1800, eds. Heidi Brayman Hackel and Catherine E. Kelly (Philadelphia: University of Pennsylvania Press, 2008); Peter Earle, "The Female Labour Market in London in the late Seventeenth and Early Eighteenth Centuries," Economic History Review 42 (1989): 328-53. 
However, more than half of the owners' inscriptions that I have collected to date are women. Given the literacy issues and the resources needed to write one's name in a book — quill, ink, time-I see these women inscribers as the tip of the iceberg of women readers.

These various books illustrate some of the ways that close attention to specific copies of books can offer unexpected insights into these works' production and consumption. Whether we look at the circulation of knowledge between manuscript and print, or the ways that everyday experiences — or careful reading — can be translated into written knowledge, or even the way that an illustration can acquire political meaning, we can see books as far more than static repositories of knowledge. They were tools in knowledge making as well. Because the material forms of our sources can tell us much, we cannot always anticipate what a future historian might find thought-provoking. Books such as Sarah's stitched-together copy of the Masterpiece, or the annotated copy of the Hortus Sanitatis, were once considered somewhat second-rate in terms of book-collecting, copies not pristine and perfect. Today we see these books as doubly informative, telling us about both authors and readers, revealing the silent and often invisible ultimate purpose of books: to be read. 